\title{
Comparative Analysis of SME Policy: The Takeaway for Bangladesh
}

\author{
Tahsina Haque Simu ${ }^{1 *}$ Dr. Mosaddak Ahmed Chowdhury ${ }^{2}$ \\ 1.Assistant Professor, Dept. of Business Administration, Shahjalal University of Science and Technology, \\ Sylhet-3114 \\ 2.Professor, Dept. of Business Administration, Shahjalal University of Science and Technology, Sylhet-3114
}

\begin{abstract}
Small and Medium Enterprises has been in attention of researchers for their potential in accelerating economic growth. Hence, SME policy is vital in ensuring the economic development of any country. Comparing the SME policy in different parts of the world can shed light on issues related to SME development. Bangladesh is trying to emphasize on SME growth and enhancement. Therefore this study aims to compare different SME policies and uncover the areas where Bangladesh needs improvement.
\end{abstract}

Keywords: Small and Medium Enterprises (SME), Policy Analysis

DOI: $10.7176 / \mathrm{EJBM} / 11-21-03$

Publication date:July $31^{\text {st }} 2019$

\section{Introduction}

One long lasting debate in global development concerns the role played by SMEs in economic development. The economic impact by SMEs across the globe can be represented in terms of employment creation, Gross Domestic Product contribution, export earnings and the output (sales volume) generation. The popular misconception that developed economies are dominated by huge corporations is proved incorrect as 99 percent of all independent enterprises in USA dominate the market, accounting for 52 percent of all workers (U.S. Small Business Administration (SBA)). According to the United States Department of State, "some 19.6 million Americans work for companies employing fewer than 20 workers, 18.4 million work for firms employing between 20 and 99 workers, and 14.6 million work for firms with 100 to 499 workers; by contrast, 47.7 million Americans work for firms with 500 or more employees." Small and medium-sized enterprises (SMEs) represent $99 \%$ of all businesses in the European Union(EU). In the past five years, they have created around $85 \%$ of new jobs and provided twothirds of the total private sector employment in the EU. The total number of SMEs in Bangladesh is estimated to be 79,00,000 establishments. Of them, 93.6 percent are small and 6.4 percent are medium. The country's SME sector has created 15 lakh jobs between 2009 and June 2014. Therefore, this study is based on a comparative analysis of policies of North America, European Union and Bangladesh's SMEs.

\subsection{Objectives}

The research study's main aim was to compare the policies taken for SMEs in USA, EU and Bangladesh.

\subsection{Justification of the study}

Bangladesh is operating in different policy environment than those in USA and EU. A comparative analysis can shed light on the areas where Bangladesh needs improvement.

\section{Literature Review}

Small and medium-sized entities (SMEs) play important roles in economic growth and sustainable development of every nation, (Moore et al., 2008). The growth of SMEs is a critical ingredient in the sustainable development of developing economies (Mudavanhu et al., 2011). According to Storey and Westhead (1994), SMEs are regarded as the seed-bed for the development of large companies and are the life blood of commerce and industry at large. SMEs have been identified as sources of innovation and business evolution (Wynarczyk et al., 1993). Globally, Small to medium enterprises are being hailed for their pivotal role in promoting grassroots economic growth and equitable sustainable development (Munyanyiwa, 2009). Literature noted that in the USA and EU countries it is estimated that SMEs contribute 40-60 percent to Gross Domestic Product and 30 to 60 percent in exports. It is also highlighted that Asian Tigers such as India, Indonesia, China, Malaysia, Japan and South Korea also have thriving SME sectors contributing between 70 to 90 percent in employment and an estimated of over 40 percent contribution in their respective GDPs (SBC,2015). Whilst in African power houses such as South Africa, Egypt, Nigeria and Kenya, the SME sector is estimated to contribute over 70 percent in employment, and 30 to 40 percent contribution to GDP (Munyanyiwa 2009). SMEs are confronted by a number of opportunities and challenges. Some of these opportunities and challenges are caused by the SMEs themselves, some are caused by the corporate world while others are caused by government policies and legislation. Of importance in this study are the opportunities and challenges that relate to government policies, legislation and actions. The government, through 
its policies and legislation acts as both a barrier and a facilitator of the establishment and development of SMEs.

\section{Definition of SME in different context}

Small Medium Enterprises has been defined and used differently in various contexts. Definitions vary between industries, countries and even between studies (Davidson, 1989). A small firm in the USA, for example, is not necessarily a small firm in the Bangladesh business environment.

\begin{tabular}{|c|c|c|c|c|}
\hline \multirow[t]{4}{*}{ EU } & Company Category & Employees & Turnover (Euro) & Balance Sheet Total \\
\hline & Micro & $<10$ & $<2$ million & $<2$ million \\
\hline & Small & $<50$ & $<10$ million & $<10$ million \\
\hline & Medium-Sized & $<250$ & $<50$ million & $<43$ million \\
\hline \multirow[t]{4}{*}{ USA } & Manufacturing & $<500$ & & \\
\hline & Wholesale & $<100$ & & \\
\hline & $\begin{array}{l}\text { Mining(Copper Ore and } \\
\text { Nickel Ore Mining) }\end{array}$ & $<1500$ & & \\
\hline & Mining(Silver Ore Mining) & $<250$ & & \\
\hline \multirow[t]{2}{*}{ Canada } & $\begin{array}{l}\text { Small(Manufacturing) } \\
\text { Small(Service) }\end{array}$ & $\begin{array}{l}<100 \\
<50\end{array}$ & & \\
\hline & Medium-Sized & $<500$ & & \\
\hline Bangladesh & & & \multicolumn{2}{|c|}{$\begin{array}{l}\text { Fixed Assets other than Land and Buildings } \\
\text { (Taka) }\end{array}$} \\
\hline \multirow[t]{3}{*}{ Small Ent } & Service & $=<25$ & \multicolumn{2}{|c|}{$50,000-50,00,000$} \\
\hline & Business & $=<25$ & \multicolumn{2}{|c|}{$50,000-50,00,000$} \\
\hline & Industrial & $=<50$ & \multicolumn{2}{|c|}{$50,000-1,50,00,000$} \\
\hline \multirow[t]{3}{*}{ Medium Ent } & Service & $=<50$ & \multicolumn{2}{|c|}{$50,00,000-10,00,00,000$} \\
\hline & Business & $=<50$ & \multicolumn{2}{|c|}{$50,00,000-10,00,00,000$} \\
\hline & Industrial & $=<150$ & \multicolumn{2}{|c|}{$1,50,00,000-20,00,00,000$} \\
\hline
\end{tabular}

Compiled from Official Journal of EU, 20 May, 2003, Table of Small Business Size Standards, NAICS, SBA, Govt. of Canada, Bangladesh Bank

However the different variables that are widely used include the number of employees, the capital base, annual sales, fixed assets employed, level of turnover, type of business, and some combination of these. It may also vary from industry to industry (as it does in the U.S.). Because of SME contribution to the economy and greater difficulty in obtaining financing, SMEs are often given incentives and more favorable tax treatment. Governments may use a range of policies to encourage the growth of SMEs.

\subsection{Policy Analysis}

The "Small Business Act" for Europe (SBA), adopted in June 2008, has served as the framework for guiding SME policy-making, based on a set of voluntary policy recommendations centred on the following 10 principles: Entrepreneurship; 'Second chance'; 'Think small first'; 'Responsive administration'; State aid \& public procurement; Access to finance; Single Market; Skills \& Innovation; Environment; and Internationalisation. The overall objective of the SBA is to reduce administrative burdens, foster entrepreneurship, improve access to finance and markets, and overall, to improve the conditions for SMEs to develop and grow. It is a European Commission initiative to further strengthen SMEs' sustainable growth and competitiveness. SBA is a set of 10 principles to guide the conception and implementation of policies both at EU and Member State level to bring added value at EU level, create a level playing field for SMEs and improve the legal and administrative environment throughout the EU. 


\begin{tabular}{|c|c|c|c|c|c|}
\hline & Policy Dimension & $\mathbf{E U}$ & USA & Canada & Bangladesh \\
\hline 1. & $\begin{array}{l}\text { Entrepreneurial } \\
\text { Learning and } \\
\text { women's } \\
\text { entrepreneurship }\end{array}$ & $\begin{array}{l}\text { Create an } \\
\text { environment in } \\
\text { which } \\
\text { entrepreneurs and } \\
\text { family businesses } \\
\text { can thrive and } \\
\text { entrepreneurship } \\
\text { is rewarded }\end{array}$ & $\begin{array}{l}\text { entrepreneurial } \\
\text { training, } \\
\text { spread } \\
\text { awareness, } \\
\text { get input on } \\
\text { today's most } \\
\text { pressing business } \\
\text { challenges. } \\
\text { award women- } \\
\text { owned small } \\
\text { businesses } \\
\text { recognizing the } \\
\text { critical } \\
\text { contributions of } \\
\text { America's } \\
\text { entrepreneurs } \\
\text { and small } \\
\text { business owners. }\end{array}$ & $\begin{array}{l}\text { Supporting women } \\
\text { entrepreneurs in a } \\
\text { diversity of industries } \\
\text { pursue export- } \\
\text { oriented Projects. } \\
\text { SME internship } \\
\text { program. } \\
\text { Action plan for } \\
\text { women } \\
\text { entrepreneurship } \\
\text { development. } \\
\text { Indigenous owned } \\
\text { SME development }\end{array}$ & $\begin{array}{l}\text { Position } \\
\text { women } \\
\text { entrepreneurs } \\
\text { into the } \\
\text { mainstream } \\
\text { business } \\
\text { community. } \\
\text { Develop } \\
\text { human } \\
\text { resources for } \\
\text { SMEs. }\end{array}$ \\
\hline 2. & $\begin{array}{l}\text { Bankruptcy and } \\
\text { second chance for } \\
\text { SMEs }\end{array}$ & $\begin{array}{l}\text { Ensure that } \\
\text { honest } \\
\text { entrepreneurs } \\
\text { who have faced } \\
\text { bankruptcy } \\
\text { quickly get a } \\
\text { second chance }\end{array}$ & & & \\
\hline 3. & $\begin{array}{l}\text { Regulatory } \\
\text { framework for } \\
\text { SME policy } \\
\text { making }\end{array}$ & $\begin{array}{l}\text { Design rules } \\
\text { according to the } \\
\text { "Think Small } \\
\text { First" principle }\end{array}$ & $\begin{array}{l}\text { Cut unnecessary } \\
\text { or ineffective } \\
\text { rules that stifle } \\
\text { business. } \\
\text { Modernize } \\
\text { requirements to } \\
\text { better help small } \\
\text { businesses. } \\
\text { Simplify and } \\
\text { streamline } \\
\text { processes so that } \\
\text { the SBA operates } \\
\text { more efficiently. }\end{array}$ & & $\begin{array}{l}\text { Strengthen } \\
\text { regulatory and } \\
\text { legislative } \\
\text { framework in } \\
\text { favor of SMEs }\end{array}$ \\
\hline 4. & $\begin{array}{l}\text { Operational } \\
\text { environment for } \\
\text { SMEs }\end{array}$ & $\begin{array}{l}\text { Make public } \\
\text { administrations } \\
\text { responsive to } \\
\text { SMEs' needs }\end{array}$ & & & \\
\hline
\end{tabular}




\begin{tabular}{|c|c|c|c|c|c|}
\hline & Policy Dimension & $\mathbf{E U}$ & USA & Canada & Bangladesh \\
\hline 5. & $\begin{array}{l}\text { a. Support services } \\
\text { for SMEs and } \\
\text { start-ups } \\
\text { b.Public } \\
\text { procurement }\end{array}$ & $\begin{array}{l}\text { Adapt public } \\
\text { policy tools to } \\
\text { SME needs: } \\
\text { facilitate SMEs' } \\
\text { participation in } \\
\text { public } \\
\text { procurement and } \\
\text { better use State } \\
\text { Aid possibilities } \\
\text { for SMEs }\end{array}$ & $\begin{array}{l}\text { encourages } \\
\text { shoppers to } \\
\text { support small } \\
\text { brick and mortar } \\
\text { businesses. } \\
\text { Surety bonds } \\
\text { help small } \\
\text { businesses win } \\
\text { contracts by } \\
\text { providing the } \\
\text { customer with a } \\
\text { guarantee }\end{array}$ & $\begin{array}{l}\text { Encouraging the } \\
\text { growth of small and } \\
\text { medium-sized } \\
\text { businesses via a } \\
\text { network of } 24 \\
\text { Community Futures } \\
\text { Development } \\
\text { Corporations spread } \\
\text { out across the region. } \\
\text { b. encourages SME } \\
\text { participation in } \\
\text { federal govt. } \\
\text { procurement. } \\
\text { Indigenous owned } \\
\text { business in federal } \\
\text { govt procurement } \\
\text { activities }\end{array}$ & $\begin{array}{l}\text { Ensure } \\
\text { availability of } \\
\text { business } \\
\text { support } \\
\text { services for } \\
\text { SMEs } \\
\text { Cluster based } \\
\text { SME } \\
\text { development } \\
\text { Identify } \\
\text { problems \& } \\
\text { prospects of } \\
\text { SMEs/SME } \\
\text { sectors/SME } \\
\text { cluster for } \\
\text { designing } \\
\text { appropriate } \\
\text { development } \\
\text { interventions }\end{array}$ \\
\hline 6. & $\begin{array}{l}\text { Access to finance } \\
\text { for SMEs }\end{array}$ & $\begin{array}{l}\text { Facilitate SMEs' } \\
\text { access to finance } \\
\text { and develop a } \\
\text { legal and business } \\
\text { environment } \\
\text { supportive to } \\
\text { timely payments } \\
\text { in commercial } \\
\text { transactions }\end{array}$ & $\begin{array}{l}\text { increase access } \\
\text { to capital for } \\
\text { rural small } \\
\text { businesses. } \\
\text { SBA provides } \\
\text { loans, low- } \\
\text { interest disaster } \\
\text { loans } \\
\text { financial awards } \\
\text { in order to } \\
\text { help small } \\
\text { businesses with } \\
\text { export } \\
\text { development. } \\
\text { Ensure disaster } \\
\text { victims receive } \\
\text { financial } \\
\text { assistance } \\
\text { quickly to } \\
\text { rebuild and } \\
\text { recover. }\end{array}$ & $\begin{array}{l}\text { The Canada Small } \\
\text { Business Financing } \\
\text { Program makes it } \\
\text { easier for small } \\
\text { businesses to obtain } \\
\text { loans from financial } \\
\text { institutions because } \\
\text { the government } \\
\text { shares the risk with } \\
\text { the lenders. } \\
\text { Small business tax } \\
\text { rate, tax credit } \\
\text { (enhanced investment } \\
\text { tax credit), employee } \\
\text { insurance premium } \\
\text { Specialized and } \\
\text { personalized business } \\
\text { and financial services } \\
\text { to SMEs related to } \\
\text { farming }\end{array}$ & $\begin{array}{l}\text { Access to } \\
\text { institutional } \\
\text { finance for } \\
\text { SMEs }\end{array}$ \\
\hline 7. & $\begin{array}{l}\text { Standards and } \\
\text { technical } \\
\text { regulations }\end{array}$ & $\begin{array}{l}\text { Help SMEs to } \\
\text { benefit more from } \\
\text { the opportunities } \\
\text { offered by the } \\
\text { Single Market }\end{array}$ & & & $\begin{array}{l}\text { Institutional } \\
\text { linkage for } \\
\text { SME } \\
\text { development }\end{array}$ \\
\hline
\end{tabular}




\begin{tabular}{|c|c|c|c|c|c|}
\hline & Policy Dimension & $\mathbf{E U}$ & USA & Canada & Bangladesh \\
\hline 8. & $\begin{array}{l}\text { a. Enterprise skills } \\
\text { b. Innovation } \\
\text { policy for SMEs }\end{array}$ & $\begin{array}{l}\text { Promote the } \\
\text { upgrading of } \\
\text { skills in SMEs } \\
\text { and all forms of } \\
\text { innovation }\end{array}$ & $\begin{array}{lr}\text { encourage } & \text { small } \\
\text { firms } & \text { to } \\
\text { undertake } & \\
\text { scientific } & \\
\text { research } & \text { that } \\
\text { helps } & \text { meet } \\
\text { federal research } \\
\text { and development } \\
\text { objectives and } \\
\text { haverrar high } \\
\text { potential for } \\
\text { commercializatio } \\
\mathrm{n} \text { if successful. }\end{array}$ & $\begin{array}{l}\text { Digital Skills for } \\
\text { Youth connects } \\
\text { underemployed with } \\
\text { small businesses } \\
\text { The Patent Collective } \\
\text { Pilot Program will } \\
\text { help small to } \\
\text { medium-sized } \\
\text { enterprises better } \\
\text { leverage intellectual } \\
\text { property in their drive } \\
\text { to grow to scale and } \\
\text { compete in the } \\
\text { innovative economy. }\end{array}$ & $\begin{array}{l}\text { Up-gradation } \\
\text { and adoption } \\
\text { of appropriate } \\
\text { technology for } \\
\text { SMEs } \\
\text { Adaptation of } \\
\text { Information } \\
\text { and } \\
\text { Communicatio } \\
\mathrm{n} \text { Technology } \\
\text { (ICT) in SME } \\
\text { Development }\end{array}$ \\
\hline 9. & $\begin{array}{l}\text { SMEs in a green } \\
\text { economy }\end{array}$ & $\begin{array}{l}\text { Enable SMEs to } \\
\text { turn } \\
\text { environmental } \\
\text { challenges into } \\
\text { opportunities }\end{array}$ & & & \\
\hline 10. & $\begin{array}{l}\text { Internationalisation } \\
\text { of SMEs }\end{array}$ & $\begin{array}{l}\text { Encourage and } \\
\text { support SMEs to } \\
\text { benefit from the } \\
\text { growth of markets }\end{array}$ & & $\begin{array}{l}\text { Supporting the } \\
\text { commerce } \\
\text { efforts; Expanding } \\
\text { and diversifying } \\
\text { commercial } \\
\text { relationships with } \\
\text { emerging and high- } \\
\text { growth markets; } \\
\text { export financing } \\
\text { solutions }\end{array}$ & \\
\hline
\end{tabular}

Table 2: Comparative Scenario

\subsection{The Takeaways for Bangladesh}

We take the 10 policy dimensions of European Commission as the benchmark to evaluate the strategies taken to promote SMEs in other locations. We can find that Bangladesh has missing policy in the following four dimensions:

- Bankruptcy and second chance for SMEs

- Operational environment for SMEs

- SMEs in a green economy

- Internationalisation of SME

Of the above mentioned four, the last two policy areas can play a vital role in the SME development in Bangladesh. SMEs in a green economy means achieving economic growth without forfeiting the well-being environment.

Also, the internationalization of SMEs is very crucial as the SME performance depends on export capacity and hence contribution to economy.

\section{Conclusion}

Bangladesh is thriving to accelerate the economic growth by promoting its SMEs. A good starting point could be comparing the SME policies with those in developed economies. In this way it would be easier to identify the policy areas ignored in the policy design for SME development in Bangladesh.

\section{References}

Moore WC, Petty JW, Palich CH, Longernecker JG (2008). Managing Small Business: An entrepreneurial emphasis, 14th ed.

Mudavanhu V, Bindu S, Chigusiwa L, Muchaiwa L (2011), Determinants of Small and Medium Enterprises Failure in Zimbabwe, International Journal Of Economics Research, vol 2 No 5, pp.83-89.

Wynarczyk KP, Watson R, Storey DJ, Short H, Keasy K (1993). The Managerial Labour Market in Small and Medium-sized Enterprises, Routledge

Westhead P, Reynolds P and Storey P (1994) "A Cross -National Comparison of the Variation in new firm formation rates, Regional Studies 28 No.4, pp 443-56 
European Commission: https://ec.europa.eu/growth/smes_en

Annual report on European SMEs 2018: https://ec.europa.eu/growth/smes/business-friendlyenvironment/performance-review_en

Small Business Administration USA: https://www.sba.gov/

Government of Canada: The official website https://www.canada.ca/en.html

SME Foundation, Bangladesh: http://www.smef.org.bd/v2/index.php?popup_anywhere_preview=true

Bangladesh Bank: https://www.bb.org.bd/sme/smepolicye.pdf 